Volume 11 Number 1, January-March 2017: pp. 30-38 . Copyright (c) 2017 FIAT JUSTISIA. Faculty of Law, Lampung University, Bandarlampung, Lampung, Indonesia. ISSN: 1978-5186 | e-ISSN: 2477-6238.

Open Access: http://jurnal.fh.unila.ac.id/index.php/fiat

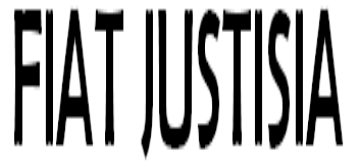

Fiat Justisia is licensed under a Creative Commons Attribution 4.0 International License, which permits unrestricted use, distribution, and reproduction in any medium, provided the

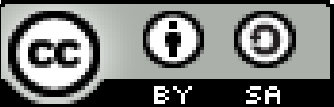
original work is properly cited.

\title{
An Examination of Customary and Statutory Legal Meaning of a Child in Nigeria: a Stream of Two Water that does not Mix
}

\author{
Akpa Michael Ajanwachuku \\ Faculty of Law, Ebonyi State University Abakaliki, Nigeria \\ majanwchuku@yahoo.com
}

\begin{abstract}
The Nigerian legal system is pluralistically consisting of statutory law, which is derived from received English law and native customary law. The latter is made subservient to the former through the validity tests. This paper examined the position of the two regimes on the meaning and definition of the child and the legal consequences that arise from it. The paper found that while the two legal regimes conceptualize the 'child' differently, there is an acute internal divergence of who a child is, within each of these regimes. The paper recommended both the internal and intersystemic harmonization of the meaning and definition of the child within the Nigerian legal system.
\end{abstract}

Keywords: Nigerian Child, Customary Law, Statutory Law, Validity Tests, Child's Rights Act

\section{A. Introduction}

Before the introduction of English law in Nigeria by Ordinance No. 3 of 1863, customary law was the extant law in Nigeria. By 1863, two legal regimes were therefore in existence in Nigeria that co-existed side-by-side. Where a subject matter related to the practice of the people, the customary law applied and vice versa concerning received English law and its applicability to transactions completed under it. Customary law is based exclusively on the native laws and custom of the people, which is culled from the way of life of the people. The existence of the two legal regimes in Nigeria created a lot of conflicts, hence the institution of the validity tests to restrict the applicability of the customary law. These tests require that customary law must not be repugnant to natural justice, equity, and good 
conscience or incompatible with any written law on the same subject matter, or contrary to public policy. ${ }^{1}$ Thus, on a particular subject matter, the two legal regimes may stipulate different norms, which are not, however, incompatible and therefore, co-exist as separate norms applicable to different sets of people and circumstance.

In Nigeria, customary law and statutory law (received English law) are complete sets of laws, which cover all fields of human existence, including the subject matter of this paper; the meaning of a child. The meaning of child, therefore, exists under customary law and English law. Both legal regimes conceptualize the 'child' differently. They do not only define the 'child' using different parameters but also derive different legal consequences from their varied conceptualizations relating to the civil and criminal capacity of the child, inheritance, proprietary capacity and sociopolitico-legal dimensions of human capacity. These legal consequences subsist within the sphere of influence of the two legal regimes in Nigeria without any substantiate conflict. This paper intends to explain this divergent stream of two water that hardly mix within the confluence of the same jurisdiction in Nigeria on the meaning of a child and the consequences that derive from it. The paper shall forensically analyze the identical yet, distinct provisions on the meaning of the Nigerian child in the extant legal regimes.

\section{B. Analysis And Discussion}

\section{Nigerian Child under Customary Law}

Customary law in Nigeria is derived from the customs, traditions, and practices of the people, which represent their way of life. To that extent, customary law is multiplied into at least 250 places in Nigeria, representing the approximately 350 ethnic tribes in Nigeria. It differs from people to people, place to place or tribe to tribe. It is indeed is the major shortcoming of Nigerian customary law, which is its absence of homogeneity. ${ }^{2}$ Thus, regarding the subject matter of this paper, customary law meaning of a child in Nigeria is multiplicated. Whether or not a person is a child is dependent on the customary law of the area where the issue has arisen for determination. Within the customary law of an area, however, whether or not

\footnotetext{
${ }^{1}$ See generally, section 18(3) of the Nigerian Evidence Act 2011; section 20(1) of Ebonyi State High Court Law Cap. 92, Laws of Ebonyi State of Nigeria, 2009 ("the Court shall observe and enforce the observance of customary law and shall not deprive any person of the benefit thereof except when any such customary law is incompatible either directly or by its implication, with any law for the time being in force in the State").

2 A. Obilade, The Nigerian Legal System, (London: Sweet \& Maxwell, 1981) 83; Okonkwo (ed.) Introduction to Nigerian Law, (London: Sweet \&Maxwell, 1980) 41; Labinjoh v. Abake (1924) 5 NLR 33.
} 
a person is a child is dependent on the purpose for which the inquiry is being made.

For instance, in several ethnic groups in Nigeria, ${ }^{3}$ financial independence and contribution to community and family concerns is a yardstick for determination of adulthood. Children are not required to financially contribute to development projects in the community or contribute to solving family challenges. Thus, a person who has attained the statutory age of adulthood in Nigeria, ${ }^{4}$ but is unable to make financial contributions to community development may be presumed under many prevailing native customs in Nigeria to be a child. ${ }^{5}$ The same situation applies to family matters. The African extended family system guarantees that every member of the extended family must participate in solving family problems, which include financial contributions. Any member of the family who is given reasonable time, but is unable to make the required contributions towards the resolution of any family issue is considered a child and treated accordingly, especially if he still depends on the parents or relatives for sustenance. ${ }^{6}$

The logic of this native custom is that, like children who are funded for by others, any mature person who is unable to meet up with his obligations either to the community or family is not fit to be called an adult, which carries some dignity and responsibilities. The determination of childhood is therefore anchored on the fact that the person whose age has fallen for determination has not attained the mental and social adaptation to his environment to be able to confront and solve the problems of life. An adult who cannot solve his problems without the supervision or intervention of the parents or relatives or another adult is just like a child and is deemed to be one. ${ }^{7}$ Their parents and relatives solve their problems and continue to do so until they are matured in belongs to for themselves.

Again, among the Ibo ethnic group of Nigeria, (which the author belongs) to membership of an age grade is evidence of cessation of

\footnotetext{
${ }^{3}$ Nigeria has over 350 ethnic groups. See O. Otite, Ethnic Pluralism and Ethnicity in Nigeria, (Shaneson C.I; 1990), pp.47-45 in I. Ayua and Okagbue (eds.). (1996). The Rights of the Child in Nigeria. Lagos: Nigerian Institute of Advanced Legal Studies, p. 30.

${ }^{4}$ The age of 18 years or above as stated in section 277 of the Nigerian Child's Rights Act, cap. C50 Laws of the Federation of Nigeria, 2010.

${ }^{5}$ Ayua and Okagbue, Loc.Cit.

${ }^{6}$ See Onibokun, O.M. (1986 ). "Child Protection Measures: Review of Policies and Laws Protecting Children from Abuse in Nigeria", in UNICEF Child Protection in Nigeria: Summary of Research Findings on Protection and Violation of Children's Rights. Lagos: Jeromeliaho \& Associates Ltd., p. 47.

7 See Oloko, S.B.A. (1986 ). "Introduction: Protection and Violation of Child Rights in Nigeria", in UNICEF Child Protection in Nigeria: Summary of Research Findings on Protection and Violation of Children's Rights. Lagos: Jeromelaiho \& Associates Ltd., p. 1.
} 
childhood. Membership is acquired through initiation, and the effect is that it raises the presumption of adulthood. ${ }^{8}$ Thus, in the Eastern region of Nigeria, which is predominated by the Ibos, a male person who has not undergone initiation rites into an age group is not only deemed a child but also presumed to be a woman and treated as such, so long as he remains uninitiated.

Another status determinant in the Ibo native law and customs is the attachment of the first male child to the father's legacy, which requires that he remains a child for family rituals and socio-politico-legal succession as long as the father is still alive. This custom seems to be widely applicable to the different tribes of Nigeria. Thus, among the Jukuns, ${ }^{9}$ a father is bound to provide accommodation for his adult male children, especially the first male child who will succeed him. It was illustrated in the case of Awudu $v$. Daniel $^{10}$ where the Nigerian Court of Appeal held that a father was bound to provide accommodation for his first son who was more than 30 years of age. ${ }^{11}$ In this case, the $1^{\text {st }}$ defendant, the father of the plaintiffs bought a piece of land in Wukari town and commenced development at a time when the $1^{\text {st }}$ plaintiff who was his first son was between one and two years old. The defendant later had another male child (the $2^{\text {nd }}$ defendant), and four daughters. All the children were begotten at the accommodation (piece of land) in dispute. In 1998, the $1^{\text {st }}$ defendant divorced the mother of the plaintiffs and in that same year proceeded to sell the building wherein the $1^{\text {st }}$ plaintiff and his siblings (the four sisters) were born, to the $2^{\text {nd }}$ defendant. The sale was without notice to the plaintiffs, who filed this suit for themselves and on behalf of the four sisters, seeking inter alia a declaration that the sale was void. The High Court found for the plaintiffs and the defendants unsuccessfully appealed to the Court of Appeal; at which the Court of Appeal held inter alia as follows:

Under Jukun native law and custom, a father must provide shelter for his children. Also, a father is not allowed to sell the compound in which his children are living or family land. If he wishes to sell, he must notify them and his wife, but if they refuse, he cannot sell. Where he sells in default of this, he would be obliged to return the money to the buyer if his children complain, the sale would be nullified. But a Jukun person can sell his house in which he is not living with his children without their consent. However, children

\footnotetext{
${ }^{8}$ See Ayua and Okagbue (eds.). Loc.Cit.

9 "Jukuns" is a tribe in the North-Central and North-East geo-political zones of Nigeria, comprised of the following States: Benue, Nasarawa, Plateau, Adamawa, Gombe and Taraba. ${ }^{10}$ (2005) 2 NWLR (Pt. 909) 199.

${ }^{11}$ Per Mukhtar, Sanusi and Nzeako JJ.C.A.
} 
do not inherit their father's property while he is still alive under Jukun's native law and custom.

In the vast majority of native customs in Nigeria, a male person ceases to be a child on the day of his marriage, and conversely, a mature male person continues to be denigrated as a child if he remains unmarried. In other customs, whether or not a person is a child is a matter of impression and opinion of the people of the area concerned. Thus, a report by the Nigerian Institute of Advanced Legal Studies reveals that in certain customs, a child is a person below 20 years of age, while in others; a child is a person who is below 30 years of age. ${ }^{12}$

From the preceding, it is quite clear that there is no readily ascertainable age of cessation of childhood under Nigerian customary laws, because generally, whether or not a person is a child is an issue of circumstance and not age. Notwithstanding, the general rule in most customs is that a child is a person who has not attained the age of puberty, because "native law and custom decree that persons come of age when they reach the age of puberty." "13

\section{Nigerian Child under Statutory Law}

Nigerian statutory law is far from cohesive on whom a child is. Various statutes provide for different ages to define a child for different purposes. To determine the issue of parties to crimes and criminal responsibility, the two principal criminal law statutes in Nigeria, the Criminal Code ${ }^{14}$ and Penal Codes ${ }^{15}$ distinguish between two age categories to define a child. Under the Criminal Code as in the Penal Code, a person below the age of 7 years is doli incapax and cannot be criminally liable for any crime in Nigeria. ${ }^{16}$ The Criminal Code further extends this restriction to a male child below 12 years for the offense of unlawful carnal knowledge ${ }^{17}$ only. However, for any other offense, a person of below the age of 12 years is not criminally responsible "unless it is proven that at the time

\footnotetext{
${ }^{12}$ See Onibokun, O.M. Loc. Cit.

${ }^{13}$ See Labinjoh v. Abake (1924) 5 NLR 33.

${ }^{14}$ Criminal Code Act Cap. C38 Laws of the Federation of Nigeria 2010. The Act applies in the Southern States of Nigeria made up of Abia, Akwa-Ibom, Anambra, Bayelsa, Cross River, Delta, Ebonyi, Edo, Ekiti, Enugu, Imo, Lagos, Ogun, Ondo, Osun, Oyo and Rivers States

${ }^{15}$ Penal Code Law Cap. 89, Laws of Northern Nigeria, 1963. The Act applies in the Northern States of Nigeria made up of Adamawa, Bauchi, Benue, Borno, Gombe, Jigawa, Kaduna, Kano, Kastina, Kebbi, Kogi, Kwara, Nasarawa, Niger, Plateau, Sokoto, Taraba, Yobe and Zamfara States as well as Abuja, the Federal Capital Territory.

${ }^{16}$ See section $30 \mathrm{CC}$ and section 50(a) PC

${ }^{17}$ Section $30 \mathrm{cc}$ "A male person under the age of twelve years is presumed to be incapable of having carnal knowledge".
} 
of doing the act or making the omission he could know that he ought not to do the act or make the omission. ${ }^{18}$ To determine the culpability of a male child in sexual offenses under the Criminal Code, therefore, a child is a person below the age of 12 years. In any other offense, however, a person of above seven years but below twelve is not a child to administrate punishment. The Penal Code contains similar provisions; however, the blanket restriction of liability for male children below the age of twelve for rape is absent. Under the Penal Code, a child of above seven years but below twelve is not criminally liable unless it is proven that he "has attained sufficient maturity of understanding to judge the nature and consequence of that act." 19 In this case, therefore, any person above seven years is not presumed to be a child for criminal liability.

Other statutory criminal provisions that deal with the definition of a child in Nigeria relates to Child Justice Administration. The Nigerian Child's Rights Act, ${ }^{20}$ which domesticates the UN Convention on the Rights of the Child and the African Charter on the Rights and Welfare of the Child, defines a child as a person below the age of 18 years. ${ }^{21}$ Section 209 of the Act provides that:-

The police, prosecutor or any other person dealing with a case involving a child offender shall have the power to dispose of the case without resorting to formal trial by using other means of settlement, including supervision, guidance, restitution, and compensation of victims and encourage the parties involved in the case to settle the case", but where the power is not exercised, and a child is tried and found guilty by the court, the term 'conviction' and 'sentenced' shall not be used in relation to [such] a child.

Several statutes on different aspects of civil law also provide for different ages of delineating a person a child based on the subject matter of

\footnotetext{
${ }^{18}$ Ibid.

${ }^{19}$ Section 50(b).

${ }^{20}$ Cap. C50 Laws of the Federation of Nigeria, 2010.

${ }^{21}$ See Article XL(3)(b) \& (4) of the UN Convention on the Rights of the Child 1990. It provides that whenever a child (a person below 18 years of age, as defined under Article 1) is alleged as, accused of, or recognised as having infringed the penal law, State parties whenever appropriate and desirable shall seek to promote "measures for dealing with such children without resorting to judicial proceedings" even as "alternatives to institutional care shall be available to ensure that children are dealt with in a manner appropriate to their wellbeing and proportionate both to their circumstances and the offence". Article XVII (2)(b) \& (3) of the African Charter on the Rights and Welfare of the Child, 1989 on the other hand, provides that whenever a child (a person below 18 years of age as defined under Article II) is accused or found guilty of having infringed penal law, State parties shall "ensure that [such] children are separated from adults in their place of detention or imprisonment" and that "the essential aim of treatment of every child during the trial and also if found guilty of infringing the penal law shall be his or her reformation, re-integration into his or her family and social rehabilitation".
} 
the particular law. Good examples are the Labour $\mathrm{Act}^{22}$ and Electoral Act. ${ }^{23}$ Under the Labour Act, a child cannot be employed or engaged to work in any industrial undertaking; and for this purpose, a child is defined as any person below the age of 14 years. ${ }^{24}$ The provision expressly mentioned 'industrial undertaking,' which by the maxim expression unius est exclusio alterios $^{25}$ eliminates other types of works. The effect, therefore, is that a person below the age of 14 is not a child and may be employed or engaged in any establishment other than an industrial undertaking. Again, a person below the age of 14 years is an adult and can be employed or engaged to work even in an industrial undertaking if it is for training in a technical school where the work is approved and supervised by the Ministry of Education or corresponding Department of Government of a State. ${ }^{26}$

The Electoral Act, on the other hand, contemplates that children are not to be part of the electoral process and thus excludes them from voting during elections. It states that a person below the age of 18 years is not entitled to be registered to vote. ${ }^{27}$ These categories of persons are, therefore, children to exercise voting rights during elections in Nigeria.

Notwithstanding the above divergent statutory provisions on the meaning of a child in Nigeria, it is submitted that the general rule under Nigerian statutory laws is that a child is a person who has not attained the age 18 years. The Nigerian Child's Rights Act is specific legislation that deals with issues of children, and therefore, its provisions must take precedence over other ancillary legislation that defines the child merely for fringe purposes.

\section{Conclusion}

We conclude in this paper that even though the two regimes of laws applicable in Nigeria: statutory and customary laws, do not conflict on the definition and application of the concept of a child, there is a need to harmonize these various divergent provisions in Nigeria in order to streamline the approach of the law to children issues. In our opinion, the best approach is to extend the application of the Child's Rights Act on the

\footnotetext{
${ }^{22}$ Labour Act Cap.L1, Laws of the Federation of Nigeria, 2010 (hereinafter simply referred to as "the Labour Act").

${ }^{23}$ Elections (Registration, Etc of Voters) Act, Cap. E5 Laws of the Federation of Nigeria, 2010 and Electoral Act, Cap. E6 Laws of the Federation of Nigeria, 2010.

${ }^{24}$ Section 59 (2) of the Labour Act.

${ }^{25}$ Meaning "The express and unambiguous mention of one thing in a statutory provision automatically excludes any other which otherwise would have applied by implication with regard to the same subject matter". See the Supreme Court of Nigeria case in Jev v. lyortum (2015) 15 NWLR (Pt. 1483) 484.

${ }^{26}$ Section 59 (2) of the Labour Act.

${ }^{27} \mathrm{Ibid}$, section 1 (2) (c); and section 12 (1) (b) of the Act.
} 
definition of a child to cover all legal issues dealing with child welfare, rights, and criminal responsibility in Nigeria. Nigeria will not be the only country that has extended the age of criminal responsibility to 18 years. ${ }^{28}$

\section{A. Book}

\section{Bibliography}

Ayua, I., and Okagbue (eds.). (1996). The Rights of the Child in Nigeria. Lagos: Nigerian Institute of Advanced Legal Studies

Obilade, A. (1981). The Nigerian Legal System. London: Sweet \& Maxwell. Okonkwo (ed.). (1980). Introduction to Nigerian Law. London: Sweet \& Maxwell.

Oloko, S.B.A. (1986 ). "Introduction: Protection and Violation of Child Rights in Nigeria," in UNICEF Child Protection in Nigeria: Summary of Research Findings on Protection and Violation of Children's Rights. Lagos: Jeromelaiho \& Associates Ltd.

Onibokun, O.M. (1986 ). "Child Protection Measures: Review of Policies and Laws Protecting Children from Abuse in Nigeria," in UNICEF Child Protection in Nigeria: Summary of Research Findings on Protection and Violation of Children's Rights. Lagos: Jeromeliaho \& Associates Ltd.

Otite, O. (1990). Ethnic Pluralism and Ethnicity in Nigeria. Shaneson C.I;

\section{B. Legislation}

(2005) 2 NWLR (Pt. 909) 199.

Brazilian Constitution.

Criminal Code Act Cap. C38 Laws of the Federation of Nigeria 2010.

Elections (Registration, Etc of Voters) Act, Cap. E5 Laws of the Federation of Nigeria, 2010.

Electoral Act, Cap. E6 Laws of the Federation of Nigeria, 2010.

Labinjoh v. Abake (1924) 5 NLR 33.

Labour Act Cap.L1, Laws of the Federation of Nigeria, 2010.

Laws of Ebonyi State of Nigeria, 2009.

Laws of the Federation of Nigeria, 2010. Cap. C50.

Penal Code Law Cap. 89, Laws of Northern Nigeria, 1963.

Penal Reform International, "The Minimum Age of Criminal Responsibility," Justice for Children Briefing No. 4, February 2013

See the Supreme Court of Nigeria case in Jev v. lyortum (2015) 15 NWLR (Pt. 1483).

\footnotetext{
${ }^{28}$ See Article 228 of the Brazilian Constitution, which states that 'Minors under eighteen years of age may not be held criminally liable and shall be subject to the rules of the special legislation'. See Penal Reform International, "The Minimum Age of Criminal Responsibility", Justice for Children Briefing No. 4, February 2013, p.1.
} 
The African Charter on the Rights and Welfare of the Child, 1989 on the other hand.

The Nigerian Child's Rights Act. Cap. C50 Laws of the Federation of Nigeria, 2010.

The Nigerian Evidence Act 2011; Section 20(1) of Ebonyi State High Court Law, Cap. 92.

The UN Convention on the Rights of the Child, 1990. 